\title{
Evaluation of Induced Microclimate Modification via Changing Planting Dates and/or Irrigation Methods on Maize Water Productivity in Two Locations in Egypt \\ Badawi, M. I.; Nematalla Y. Mokhtar and Tahany Noreldin \\ Water Requirement and Field Irrigation Research Department, Soil, Water and Environment Research Institute
}

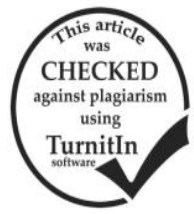

\section{ABSTRACT}

A field experiment was executed in2015 summer season, at Gemmeiza (Middle Nile Delta, Lat. 30.47, Long. 31.00) at ElGharbia Governorate and Mallawi (Middle Egypt, Lat. 28.05 Long. 30.44) at El-Minia Governorate to find out the extent to which grain yield, water use and water productivity for SC10 maize hybrid were influenced by irrigation schemes and planting dates and itinteraction. Irrigation schemes (furrow and bed irrigation schemes) were combined with three planting dates (May, 15; May, 30 and June, 14), and assessed in Randomized Complete Block Design andarranged in split plot design. Irrigation schemes were tested in main plots, while the split plots were assigned to planting dates, and each treatment was replicated three times. The important findings could be summarized as follows: * Maize grain yield at Gemmeiza location insignificantly increased thatatMallawi location. The adopted irrigation schemes significantly influenced the grain yield, and furrow irrigation surpassed bed furrow irrigation by $9.15 \%$. Maize grain yield was significantly influencedby planting dates, whereplanting on May, 15 was superior, and the grain yield was increased by 3.77 and $7.42 \%$, comparable with May, 30 and June, 14 planting dates, respectively. * The highest consumptive use (CU) value (600.5 mm) was recorded under Mallawi conditions, which exceeded that under Gemmeiza by $17.86 \%$. Such findings are mainly attributable to prevailing weather conditions during the growing season, which encourages higher crop water use under Mallawi conditions. Water use value under furrow irrigation scheme was higher by $22.24 \%$ more than that with bed irrigation. The lowest CU value $(542.3 \mathrm{~mm})$ was found for May, 15 planting date, and increased by 2.34 and 4.79\%,respectively, comparable withMay, 30 and June, 14 planting dates. *Water productivity (WP) value proved that maize plants, under Gemmeiza conditions, used the irrigation water efficiently by $10.74 \%$, higher than that recorded under Mallawi conditions. Bed irrigation scheme exhibited higher WP value than that recorded with furrow irrigation scheme by $5.15 \%$. The highest WP value $\left(7.74 \mathrm{kgfad}^{-1} \mathrm{~mm}^{-1}\right)$ resulted from May, 15 planting date, and delaying the planting date to May, 30 or June, 14 caused reductions in WP values being13.05 and 17.05\%, respectively, lower than that with May, 15 planting date. Based on the obtained results, maize production at Gemmeiza (Middle Nile Delta, Lat. 30.47 Long. 31.00), compared with Mallawi (Middle Egypt, Lat. 28.05 Long. 30.44) is preferred due to lower water use and higher water productivity as well.

Keywords: Geographic location, Maize grain yield, Water use, Water productivity.

\section{INTRODUCTION}

In Egypt, water is considered as scarce natural resource for crop production. The water demand for agriculture is about $85 \%$ of the total available water. With the rapid population increase, serious water shortage will occur and critical constrains will face the agricultural development, (FAO, 2017).

Microclimate is a climatic condition in a relatively small area, within a few meters or less above and below the Earth's surface and within canopies of vegetation. Microclimatic conditions depending on factors, such as temperature, humidity, wind and turbulence, dew, frost, heat balance, and evaporation. Microclimate could be affected due to irrigation regime and other agro management e.g. planting method, fertilization etc. Vegetation is also important, as it controls the flux of water vapor into the air through transpiration. In addition, vegetation can protect the soil below and reduce temperature variability, where the sites of exposed soil exhibited the greatest temperature variability (Encyclopædia Britannica Inc., 2007). Across a single location, there can be a significant number of different microclimates, which have different atmospheric conditions from the areas they are next to, with variations in temperature, light and water all likely to be present. The basic environmental effects and genotype environment interaction have been introduced as the most important sources of alteration for the measured yield of crops (Dehghani et al., 2006; Yan et al., 2007; Sabaghnia and Sabaghpour, 2008). Environmental variations related with different sowing dates have an altering effect on the growth and development of corn plants, where each corn hybrid has desirable planting date, and the larger the deflection from this favorite (early or late planting), the larger the yield loss (Sárvári and Futó, 2000; Berzsenyi and Lap, 2001).

The grain yield of corn (Zea mays L.) is determined by different proportional contributions of the effective factors in all growth stages from emergence to maturity. On mitigating the negative effect of some abiotic and biotic stress, sowing date and cultural practices (planting method, irrigation scheme ...etc.) can play a major role in determining the maize plant performance. So, intensive research that evaluates different geographic locations, genotypes and agricultural practices are needed for a better understanding of climatic and cultural effects on maize crop performance. In Egypt,Swelam and Atta (2012) planted maize in 15- day interval starting on May10 ${ }^{\text {th }}$ till July $11^{\text {th }}$ and they found that grain yield was decreased by $15.2,10.2,11.4$ and $23.5 \%$ for May $10^{\text {th }}$, May $25^{\text {th }}$, June $26^{\text {th }}$ and July $11^{\text {th }}$ planting dates, respectively, comparable with June $11^{\text {th }}$ date. The authors justified such findings to different climate factors affecting on growth stages duration within each planting date, which consequently affected dry matter accumulation and translocation to reproductive organs. Furthermore, the highest value of water productivity, expressed as $\mathrm{kg}$ of grain $\mathrm{m}^{-3}$ of water consumed was achieved with June $11^{\text {th }}$ planting date.

Worldwide, Koca and Canavar (2014) found that sowing date had statistically affected maize seed yield. Feyzbakhsh et al. (2015) planted maize on $22^{\text {nd }}$ of June, $6^{\text {th }}$ of July and $21^{\text {st }}$ of July and found that maize grain yield reduced when planting was delayed. However, water use efficiency increased when planting was delayed until $21^{\text {st }}$ of July. Buriro et al. (2015) reported that grain yield of 
maize varieties was significantly affected by different sowing datese.g. $25^{\text {th }}$ of October, $10^{\text {th }}$ of November and $25^{\text {th }}$ of November. The authors added that further delay of the sowing had negative effects on the performance of quantity and quality of maize.

Concerning irrigation schemes, Karrou et al. (2012) in two-season field experiment found that maize grain yield under raised bed irrigation was slightly increased, whereas WUE was higher by $29.22 \%$, comparing with traditional farmer practice. Khan et al. (2012a) reported that maize grain yield under ridge sowing was increased by $19.62 \%$, comparing with bed sowing. On the contrary,Khan et al. (2015) reported that, under 100\% field capacity irrigation level, furrow irrigated raised bed was superior than furrow irrigated ridge to increase grain yields, reduce water consumptive use and improve water use efficiency of either spring or summer maize crops. In addition,Hussain et al. (2013)stated thatwater use efficiency values were improved with ridge planting, comparable with bed furrow planting. On the contrary, Kuscu and Demir (2012) stated that, according to average of two years, the highest grain yield $\left(20.52 \mathrm{t} \mathrm{ha}^{-1}\right)$ was obtained from full irrigation, and grain yield significantly reduced as the amount and the number of irrigations decreased.

The present research aiming at investigating the extent to which geographic location, planting date, irrigation scheme (planting method) influencing maize crop productivity and water productivity under Gemmeiza and Malawi conditions in Egypt.

\section{MATERIALS AND METHODS}

In order to accomplish the research objectives, a field trial was executed at both Gemmeiza (Middle Nile Delta, Lat. 30.47 Long. 31.00)at El-Gharbia Governorate and Mallawi (Middle Egypt, Lat. 28.05 Long. 30.44) at ElMinia Governorate. Bulk density and some soil-water characteristic, and some weather factors of the experimental sites are shown in Table 1 and 2, respectively. Two experimental factors were under investigation e.g. irrigation schemes (furrow and bed irrigation schemes) combined with three planting dates (May $15^{\text {th }}$, May $30^{\text {th }}$ and June $14^{\text {th }}$ ). The adopted treatments were assessed in randomized complete block designarranged in split plot design. Irrigation schemes were tested in the main plots, while the split plots were assigned to planting dates, and each treatment was replicated three times. Each split plot contained 6 ridges, $0.7 \mathrm{~m}$ in between or 3 beds $(1.4 \mathrm{~m}$ in width). The length for both ridges and beds was $9 \mathrm{~m}$. Single Cross 10 (SC10) maize hybrid was assessed, and all the recommended agricultural practices required for high maize production were done. On grain yield determination, a guarded plant area (not less than $10 \mathrm{~m}^{2}$ ) of all the sub plots were harvested and maize grain yield was determined and expressed as $\mathrm{kgfad}^{-1}$. Homogeneity test for grain yield data at Gemmeiza and Malawi locations indicated insignificant difference. So, combined analyses of seed yield of both locations were subjected to the proper statistical analyses according to Steel and Torrie (1984) and the means were compared at 0.05 significance level.

Table 1. Some soil - water characteristics of the experimental sites.

\begin{tabular}{lcccc}
\hline $\begin{array}{l}\text { Soil } \\
\text { depth } \\
\text { (cm) }\end{array}$ & $\begin{array}{c}\text { Field } \\
\text { capacity } \\
(\mathbf{\%}, \mathbf{w t} / \mathbf{w t})\end{array}$ & $\begin{array}{c}\text { Wilting } \\
\text { Point } \\
(\mathbf{\%}, \mathbf{w t} / \mathbf{w t})\end{array}$ & $\begin{array}{c}\text { Bulk } \\
\text { density } \\
\left(\mathbf{M g ~ m}^{-3}\right)\end{array}$ & $\begin{array}{c}\text { Available } \\
\text { water, } \\
\text { mm* }^{*}\end{array}$ \\
\hline $00-15$ & 45.60 & 24.30 & 1.10 & 35.15 \\
$15-30$ & 42.30 & 22.10 & 1.20 & 36.36 \\
$30-45$ & 39.50 & 21.00 & 1.31 & 36.35 \\
$45-60$ & 36.90 & 18.60 & 1.38 & 37.88 \\
Mean & 41.10 & 21.50 & 1.18 & $\sum 145.74$ \\
\hline \multicolumn{5}{c}{ Mallawi } \\
\hline $00-15$ & 35.68 & 19.51 & 1.14 & 27.55 \\
$15-30$ & 33.33 & 18.20 & 1.18 & 26.78 \\
$30-45$ & 33.25 & 18.07 & 1.29 & 29.37 \\
$45-60$ & 33.10 & 17.90 & 1.31 & 29.87 \\
Mean & 33.90 & 18.42 & 1.23 & $\sum 113.57$ \\
\hline
\end{tabular}

*Available water, $\mathbf{m m} / 60$ of soil profile

Table 2. Some weather factors of the experimental sites, 1996-2006 mean*

\begin{tabular}{|c|c|c|c|c|c|c|}
\hline Month & $\begin{array}{c}\text { Temperature } \\
\left(\mathrm{Max} .{ }^{\circ} \mathrm{C}\right)\end{array}$ & $\begin{array}{c}\text { Temperature } \\
\left(\mathrm{Min} .{ }^{\circ} \mathrm{C}\right)\end{array}$ & $\begin{array}{c}\text { Wind speed } \\
\left(\mathrm{ms}^{-1}\right)\end{array}$ & $\begin{array}{c}\text { Relativehumidity } \\
(\%)\end{array}$ & $\begin{array}{c}\text { Rainfall } \\
\left(\text { mmmonth }^{-1}\right)\end{array}$ & $\begin{array}{c}\text { Epan } \\
\left(\text { mmday }^{-1}\right)\end{array}$ \\
\hline \multicolumn{7}{|c|}{ Gemmeiza } \\
\hline May & 32.4 & 17.3 & 4.3 & 57.8 & 0.0 & 6.1 \\
\hline June & 32.6 & 20.9 & 4.2 & 61.0 & 0.0 & 7.2 \\
\hline July & 33.7 & 22.7 & 4.3 & 65.9 & 0.0 & 7.1 \\
\hline August & 33.7 & 22.9 & 3.9 & 65.1 & 0.0 & 6.6 \\
\hline September & 32.9 & 22.6 & 4.0 & 62.0 & 0.0 & 5.4 \\
\hline \multicolumn{7}{|c|}{ Mallawi } \\
\hline May & 33.6 & 16.9 & 4.4 & 49 & 0.0 & 7.9 \\
\hline June & 35.3 & 20.6 & 4.5 & 51 & 0.0 & 8.9 \\
\hline July & 35.6 & 21.2 & 4.2 & 54 & 0.0 & 9.2 \\
\hline August & 36.1 & 21.7 & 3.9 & 57 & 0.0 & 8.0 \\
\hline September & 34.3 & 19.8 & 2.4 & 53 & 0.0 & 7.2 \\
\hline
\end{tabular}

*Supplied by Crop Water Requirements and Field Irrigation Research Department, Soil, Water and Environment Research Institute

\section{Water consumptive use (Water use):}

Soil moisture percentage was determined (on weight basis) just before and 48 hours after each irrigation as well as at harvest to compute the actual consumed water as stated by Hansen et al. (1979) as follows:
$\mathbf{C U}=\mathbf{S M D}=\sum_{\mathrm{i}=1}^{\mathrm{i}=4} \frac{\phi_{2}-\phi_{1}}{100} \times \mathbf{D}_{\mathbf{b i}} \mathbf{x} \mathbf{D}_{\mathrm{i}}$

Where:

$\mathrm{CU}=$ Water consumptive use $(\mathrm{mm})$ in the effective root zone of $60 \mathrm{~cm}$ soil depth.

$\mathrm{SMD}=$ Soil Moisture Depletion, $\mathrm{mm}$. 
$\mathrm{i}=$ Number of soil layer (1- 4).

$\mathrm{D}_{\mathrm{i}}=$ Soil layer thickness $(150 \mathrm{~mm})$.

$\mathrm{D}_{\mathrm{bi}}=$ Bulk density $\left(\mathrm{Mgm}^{-3}\right)$ of the soil layer.

$\phi_{1}=$ Soil moisture percentage $(\mathrm{wt} / \mathrm{wt})$ before irrigation and

$\phi_{2}=$ Soil moisture percentage (wt/wt), 48 hours after irrigation.

\section{Water productivity}

Water productivity with dimensions of $\mathrm{kg} \mathrm{m}^{-3}$ is

defined as the ratio of the mass of marketable yield (Ya)

to the volume of water used by the crop (ETa) as follows:

Water Productivity $\left(\mathrm{kgm}^{-3}\right)=$ Ya/ETa ...... (Molden, 2003)

\section{Where:}

$\mathrm{WP}=$ water productivity $\left(\mathrm{kgm}^{-3}\right) \mathrm{Ya}=$ maizegrain yield $\left(\mathrm{kgfed}^{-1}\right)$ and

Eta $=$ crop water use or crop evapotraspiration $\left(\mathrm{m}^{3} \mathrm{fed}^{-1}\right)$

\section{RESULTS AND DISCUSSION}

\section{A. Grain yield:}

\section{Location effect:}

Data in Table 3 indicate that maize grain yield at Gemmeiza location insignificantly increased that under Mallawi location. Indubitable, a geographic location affects performance and productivity of a distinct maize genotype due to the different prevailing environmental conditions. In this respect,Leibman et al. (2014) stated that despite genetic improvements to hybrid maize; grain yield from distinct maize hybrids is expected to vary across growing locations due to numerous environmental factors. Accordingly, distinguished variations in the performance SC10 maize hybridare predicted due to the adopted locations because of the different prevailing weather and soil characteristics. Furthermore, such variations were reported, in a given location, from growing season to another. EL-Sharkawy et al. (2008) reported that maximum maize yield at Gemmeiza reached to 3430 and $3140 \mathrm{kgfad}^{-1}$ in $1^{\text {st }}$ and $2^{\text {nd }}$ seasons, respectively. Additionally, Mahgoub et al. (2013) at same location found that yield potential of maize crop amounted to 5290 and $4410 \mathrm{kgfad}^{-1}$, respectively, in $1^{\text {st }}$ and $2^{\text {nd }}$ seasons. Similarly, at Mallawi location, variations in maize yield potential were noticed. El-Tantawy et al. (2007)reported that yield potential of maize (TWC 310 Hybrid) grown under Middle Egypt conditions, and irrigated at 1.0 CPE (Cumulated Pan Evaporation) were 7320 and $7200 \mathrm{kgha}^{-1}$ in $1^{\text {st }}$ and $2^{\text {nd }}$ seasons of the study, respectively.

Table 3. Irrigation schemes, planting dates and interaction affecting maize grain yield,Kgfed ${ }^{-1}$, under Gemmeiza and Mallawi conditionsin2015.

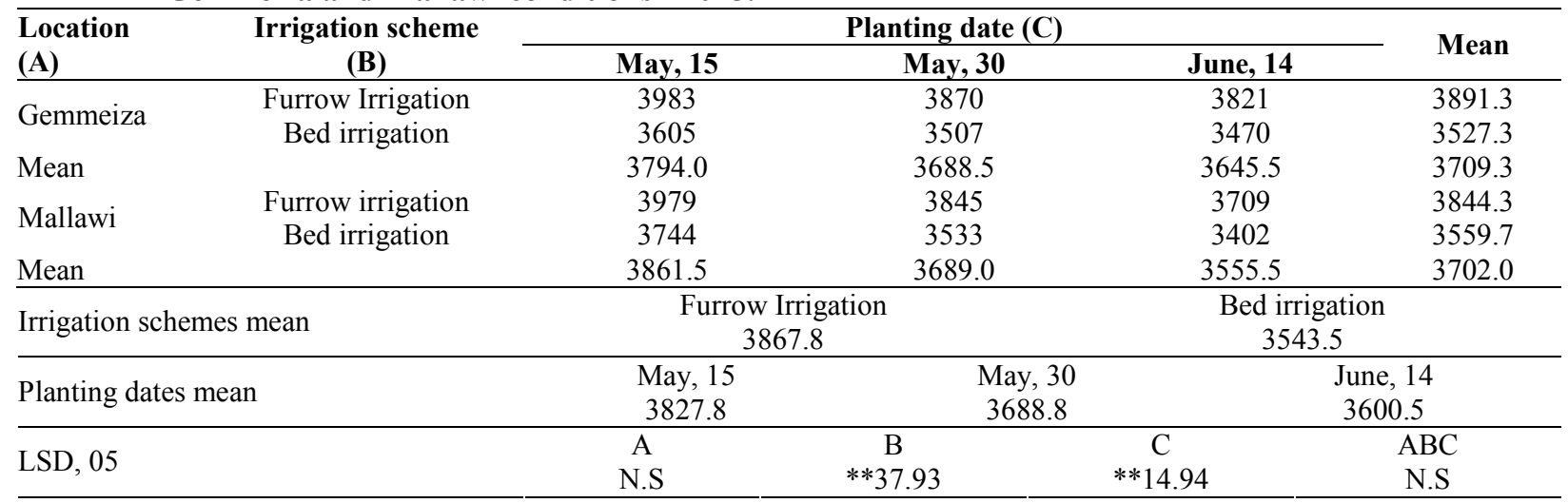

\section{Irrigation scheme effect:}

Data in Table 3 indicate that maize grain yield was significantly influenced by the adopted irrigation schemes, and furrow irrigation surpassed bed furrow irrigation by $9.15 \%$. Maize is a responsive crop to the agricultural inputs vis. Irrigation water, $\mathrm{N}$ fertilizer...etc. so, higher grain yield under furrow irrigation scheme could be attributed to higher applied water, comparing with bed irrigation. In this sense, Lamm et al. (1995) stated that it is difficult to plan deficit irrigation for maize without causing yield reduction. Furthermore, Igbadun et al. (2008) reported that deficit irrigation at any crop growth stage of the maize crop led to decrease in dry matter and grain yields, seasonal evapotranspiration, deep percolation. In connection, Irmak et al.(2016) in 3- season study, assessed the response of maize grain yield under subsurface drip irrigation to water amounts viz. $0,25,50,75$ and $125 \%$ (over-irrigation) of the fully irrigated treatment FIT (replenish the top $1.20 \mathrm{~m}$ soil profile to approximately $90 \%$ of the FC) under high frequency, where irrigation was practiced approximately every day) and found that grain yield was gradually increased up to FIT and then slightly declined with over irrigation or still unchanged. Additionally, Hussain et al. (2013) found that maize grain yield was improved by $16.67 \%$ with ridge planting, comparable with bed furrow one. Similar trends were reported by Saqib et al. (2012)who reported that ridge planting appreciably increased yield of maize compared with other planting methods. In addition, Abdul Rehman et al. (2011) in 2season investigation, reported that ridge sowing exhibited maize grain yield amounted to $25.0-24.39 \%$ higher than bed sowing. Furthermore, Khan et al. (2012a) found that maize grain yield under ridge sowing was increased by $19.62 \%$, comparing with bed sowing. In addition, Zamir et al. (2013) reported that ridge sowing was better than bed sowing with grain yield figures amounted to 6.21 and 4.51 tha $^{-1}$, respectively. Furthermore, Anjum et al. (2014) reported that, under conventional tillage practice, ridge sowing was better than bed sowing with grain yield figures amounted to 6.01 and 5.92 tha $^{-1}$, respectively. In this sense, Bakht et al. (2011) and Khan et al (2012b) justified the increase in grain yield with ridge planting, in 
comparison with bed planting, to loose fertile layer of soil that results well developed root system and consequently higher nutrient and water uptake.

\section{Planting date effect:}

Data concerning plating dates affecting maize grain yield clarify significant influences due to the adopted planting dates, Table 3. Planting maize on May, 15 surpassed both May, 30 and June, 14, where the grain yield was increased, under May, 15 by 3.77 and $7.42 \%$, comparable with May, 30 and June, 14 planting dates, respectively. In connection, Swelam and Atta (2012) planting maize in 15- days interval starting on May,10 till July, 11 and found that grain yield was decreased by 15.2, 10.2, 11.4 and 23.5\% for May 10, May 25, June 26 and July 11 planting dates, respectively, comparable with June 11 one. The authors justified such findings to different climate factors affecting on growth stages duration within each planting date, which consequently affected dry matter accumulation and translocation to reproductive organs. Koca and Canavar (2014) found that sowing date had statistically affected maize seed yield. Feyzbakhsh et al. (2015) planted maize on22 June, 6 July and 21 July and found that maize grain yield reduced when planting was delayed. Buriro et al. (2015) reported that grain yields of maize varieties were significantly affected by different sowing dates e.g. $25^{\text {th }}$ October, $10^{\text {th }}$ November and $25^{\text {th }}$ November. The authors added that further delay of the sowing had negative effects on the performance of quantity and quality of maize. Anapalli et al. (2005) found that for optimization of corn yield, planting at the appropriate time is very critical as delay in planting date can lead to a linear decrease in grain yields.

\section{B. Water Consumptive Use (CU):}

\section{Location effect:}

Crop water use is impacted by many factors, including soil and crop characteristics, climate, crop phenology and physiology, agricultural practices, soil and crop nutrients status, etc. Data in Table 4 illustrate that the highest CU value $(600.5 \mathrm{~mm})$ was recorded under Mallawi conditions, which exceeded that under Gemmeiza by $17.86 \%$. Data in Table 1 indicated that the value of available soil water in Gemmeiza is higher that its counterpart in Mallawi, which reflect the effect of different microclimate of both sites. This result implied that the applied water for maize in Gemmieza will be lower than Mallawi site. In addition, data in Table 2 referred that the higher water consumption in Mallawi is not only as a result of lower available soil water in, but also as a result of higher pan evaporation rate, which could be affected by the microclimate of this area represented in higher minimum and maximum temperature and lower relative humidity. These differences in the weather elements resulted in higher evaporation pan values in Malawi site, compared to Gemmiza site. This increase in the evaporation pan reflected the effect of microclimate in both sites, which reflected on water consumptive use for maize in each site.In this sense,Kranz et al.(2008) stated thatthe amount of daily water use by the crop will vary from season to season and location to location.El-Refaie and Khater (1996) reported that under Gemmeiza conditions, the water requirement of maize was $786 \mathrm{~mm}$. In addition, El-Garhi et al. (2007)found that CU valuereached to 669 mmfor 1.0 (irrigation water: cumulative pan evaporation) for maize grown in Middle Egypt.Additionally, El-Tantawy et al. (2007)in 2-season experimentat the same both location and irrigation regime, reported thatCU for maize (TWC 310 Hybrid) ranged $5315-5686 \mathrm{~m}^{3} \mathrm{ha}^{-1}$. EL-Sharkawy et al. (2008)irrigating maize crop via different $\mathrm{ET}_{\mathrm{O}}$ formulae, and reported that ETc ranged from 487.7 to $530 \mathrm{~mm}$ in $1^{\text {st }}$ season and from 427.9 to $500 \mathrm{~mm}$ in $2^{\text {nd }}$ one.Molua and Lambi (2006) in Cameroon, found that evapotranspiration of maize crop (ETc) is $276.9 \mathrm{~mm}$ for Ambam, $381.9 \mathrm{~mm}$ for Bamenda and $596.4 \mathrm{~mm}$ for Garoua, and the corresponding reference evapotranspiration (ETo) figures were 413, 570.1 and $890.1 \mathrm{~mm}$, respectively.

Table 4. Irrigation schemes, planting dates and interaction affecting water use for maize, mm, under Gemmeiza and Mallawi conditionsin2015.

\begin{tabular}{|c|c|c|c|c|c|}
\hline \multirow{2}{*}{ Location } & \multirow{2}{*}{ Irrigation scheme } & \multicolumn{3}{|c|}{ Planting date } & \multirow[b]{2}{*}{ Mean } \\
\hline & & May, 15 & May, 30 & June, 14 & \\
\hline \multirow{2}{*}{ Gemmeiza } & Furrow Irrigation & 544.0 & 560.0 & 571.0 & 558.3 \\
\hline & Bed irrigation & 450.0 & 462.0 & 472.0 & 461.3 \\
\hline Mean & & 497.0 & 511.0 & 521.5 & 509.8 \\
\hline \multirow{2}{*}{ Mallawi } & Furrow irrigation & 649.0 & 660.0 & 680.0 & 663.0 \\
\hline & Bed irrigation & 526.0 & 538.0 & 550.0 & 538.0 \\
\hline \multicolumn{2}{|l|}{ Mean } & 587.5 & 599.0 & 615.0 & 600.5 \\
\hline \multicolumn{2}{|c|}{ Irrigation schemes mean } & $\begin{array}{c}\text { Furrow Irrigation } \\
610.7 \\
\end{array}$ & \multicolumn{3}{|c|}{$\begin{array}{c}\text { Bed irrigation } \\
499.6 \\
\end{array}$} \\
\hline \multicolumn{2}{|c|}{ Planting dates mean } & $\begin{array}{c}\text { May, } 15 \\
542.3\end{array}$ & $\begin{array}{c}\text { May, } 30 \\
555.0\end{array}$ & \multicolumn{2}{|c|}{$\begin{array}{c}\text { June, } 14 \\
568.3\end{array}$} \\
\hline
\end{tabular}

\section{Irrigation scheme effect:}

Data in Table 4 reveal that water use value under furrow irrigation scheme was higher by $22.24 \%$ more than that with bed irrigation. Such finding could be attributed to more applied water under furrow irrigation because of the greater plot area that directly contacted with the irrigation water during water supplying compared with bed furrow. So, such situation is increasing water use through canopy transpiration and soil and canopy evaporation. Additionally, data in Table 4 also refer that the attained result may be due to the interaction effect between the microclimate of the site represented by the weather elements and both soil characteristic and irrigation scheme represented by furrow and bed irrigation. In connection, Karrou et al. (2012) reported that applied water for maize crop was higher by $38.82 \%$ (2- season mean) with traditional furrow irrigation than with raised bed irrigation. In addition, EL-Marsafawy et al.(1998), found that irrigation with $140 \mathrm{~cm}$ apart furrows, comparable with 70 $\mathrm{cm}$ apart furrows, resulted in $8 \%$ reduction in 
evapotranspiration. Moreover, Khan et al. (2015) found that furrow irrigated ridge with $100 \%$ FC gave the highest evapotranspiration, that increased by 5.20 and $6.56 \%$, respectively, with summer and spring maize, comparable with furrow irrigated raised bed.

\section{Planting date effect:}

Data in Table 4 indicate that maize water use tended to increase with delaying the planting date, which could be a result of the interaction between the microclimate of the site and the amount of water used by maize. The lowest CU value $(542.3 \mathrm{~mm})$ was noticed with May, 15 planting date, and increased by 2.34 and 4.79\% under May, 30 and June, 14 planting dates, respectively, comparable with May, 15 one. Such trend may be attributed to the gradual increase in weather conditions encouraging higher evapotranspiration rate with time advancing from May, 15 towards June, 14. In contrast, a late-planted maize crop uses less water by developing more quickly during the hotter portion of the season. Yet, the quicker development leaves less time to produce yield components and generally results in lower overall productivity, Lundy (2015).

\section{Water Productivity, WP:}

\section{Location effect:}

Water Productivity (WP) of a crop defines the relationship between the economic or physical yield of the crop and its water use.The factors influencing yield production and water use substantially caused varying WP -values over time and space, Carr et al. 2016. Data in Table5 prove that maize plants, under Gemmeiza conditions, were capable to use the irrigation water efficiently, where WP value was higher by $10.74 \%$, as compared with that recorded under Mallawi conditions. Such finding is mainly attributed to less water used by maize crop under Gemmeiza conditions. EL-Sharkawy et al. (2008)at Gemmeiza irrigating maize crop via different ETO formulae, and reported that WUE ranged $6.04-7.16 \mathrm{kgfad}-1 \mathrm{~mm}-1$ in $1 \mathrm{st}$ season and $5.81-7.34$ kgfad-1mm-1 in 2nd one. In addition, Mahgoub et al. (2013) in 2- season experiment at the same location, found that WP for maize (SC10 Hybrid) averaged $1.71 \mathrm{~kg} \mathrm{~m}-3$ on applied water basis El-Tantawy et al. (2007)in two-- season experimentat Middle Egypt, reported that WUE for maize ranged $1.27-1.38 \mathrm{kgm}-3$. In this sense, Zwart and Bastiaanssen (2004) stated that CWP value per unit water depletion for maize crop, on globally measured average amounted to $1.80 \mathrm{~kg} \mathrm{~m}-3$. The authors added that measured maize CWP values were ranging from $0.22 \mathrm{~kg} \mathrm{~m}-3$ up to a maximum of $3.99 \mathrm{~kg} \mathrm{~m}-3$, which exhibits a large range of variation $(\mathrm{CV}=0.38)$. Such variability of CWP can be ascribed to climate, irrigation water management and soil (nutrient) management, among others.

\section{Irrigation scheme effect:}

Data in Table 5 reveal thatbed irrigation scheme exhibited higher WP value than that recorded with furrow irrigation scheme by $5.15 \%$. The present results are in parallel with that reported by Karrou et al. (2012) who found, in a 2 - season field experiment with maize, that WP under raised bed irrigation surpassed that of traditional farmer practice by $29.61 \%$ (2- season mean). In addition, Khan et al. (2015) reported that furrow irrigated raised bed showed higher WUE (7.08 and $8.39 \%$ ) in case of $100 \%$ FC comparing with furrow irrigated ridge. On the contrary, Abdullah et al. (2008) reported that ridge planting appreciably increased WUE of maize compared with other planting methods. Furthermore, Khan et al. (2012b)and Hussain et al. (2013) found that WUE figures were improved with ridge planting, comparable with bed furrow planting. Such different trends may be attributed to differed experimentation conditions e.g., soil characteristics, agronomic practices, variety - environment interaction and prevailing weather conditions during the growing season.

Table 5. Irrigation schemes, planting dates and interaction affecting water productivity, $\mathrm{kgfad}^{-1} \mathrm{~mm}^{-1}$, under Gemmeiza and Mallawi conditions, 2015.

\begin{tabular}{|c|c|c|c|c|c|}
\hline \multirow{2}{*}{ Location } & \multirow{2}{*}{ Irrigation scheme } & \multicolumn{3}{|c|}{ Planting date } & \multirow{2}{*}{ Mean } \\
\hline & & May, 15 & May, 30 & June, 14 & \\
\hline \multirow{2}{*}{ Gemmeiza } & Furrow Irrigation & 7.34 & 6.91 & 6.69 & 6.98 \\
\hline & Bed irrigation & 8.01 & 7.59 & 7.35 & 7.65 \\
\hline Mean & & 7.68 & 7.25 & 7.02 & 7.32 \\
\hline \multirow{2}{*}{ Mallawi } & Furrow irrigation & 8.48 & 5.83 & 5.45 & 6.59 \\
\hline & Bed irrigation & 7.12 & 6.57 & 6.19 & 6.63 \\
\hline Mean & & 7.80 & 6.20 & 5.82 & 6.61 \\
\hline Irrigation schemes mean & \multicolumn{2}{|c|}{$\begin{array}{c}\text { Furrow Irrigation } \\
6.79\end{array}$} & \multicolumn{3}{|c|}{$\begin{array}{c}\text { Bed irrigation } \\
7.14\end{array}$} \\
\hline Planting dates mean & \multicolumn{2}{|c|}{$\begin{array}{l}\text { May, } 15 \\
7.74\end{array}$} & $\begin{array}{l}\text { May, } 30 \\
6.73\end{array}$ & \multicolumn{2}{|c|}{$\begin{array}{c}\text { June, } 14 \\
6.42\end{array}$} \\
\hline
\end{tabular}

\section{Planting date effect:}

Data in Table 5 indicate that the highest WP value $\left(7.74 \mathrm{kgfad}^{-1} \mathrm{~mm}^{-1}\right)$ resulted from May, 15 planting date. Delaying the planting date to May, 30 or June, 14 cause reductions in WP values comprised 13.05 and $17.05 \%$, respectively, lower than that with May, 15 planting date. In this sense, Swelam and Atta (2012) found that the highest value of Water Productivity for maize, ( $\mathrm{kg}$ of grain $\mathrm{m}^{-3}$ of water consumed) was achieved with June 11 planting date, and the value tended to be reduced under earlier planting (May 10 and May 25) or later planting (June 26 and July 11 planting).Feyzbakhsh et al. (2015) in 2-year experiment planted maize on 22 June, 6 July and 21 July and found that WUE increased when planting was delayed until 21 July.

On conclusion and based on the obtained results, maize production at Gemmeiza (Middle Nile Delta), compared with Mallawi (Middle Egypt), is preferred due to lower water use and higher water productivity as well. 


\section{REFERENCES}

Abdul Rehman, M. FarrukhSaleem, Muhammad Ehsan Safdar, Safdar Hussain and Naeem Akhtar (2011). Grain quality, nutrient use efficiency, and bioeconomics of maize under different sowing methods and NPK levels. Chilean J. Agric. Res., 71(4): $586-593$.

Abdullah, G.H., I.A. Khan, S.A. Khan, and H. Ali. 2008. Impact of planting methods and herbicides on weed biomass and some agronomic traits of maize. Pakistan Journal of Weed Science Research 14(34):121-130.

Anapalli S.S, Ma L, Nielsen D.C, Vigil M.F, Ahuja L.R. 2005. Simulating planting date effects on corn production using RZWQM and CERES-Maize models. Agronomy J., 17: (97): 58-71.

Anjum, S.A., Ehsanullah, Umair Ashraf, MohsinTanveer, RafiQamar, Imran Khan. 2014. Morphological and phenological attributes of maize affected by different tillage practices and varied sowing methods. American Journal of Plant Sciences, 5, 1657-1664.

Bakht, J., M. Shafi, H. Rehman, R. Uddin, and S. Anwar. 2011. Effect of planting methods on growth, phenology and yield of maize varieties. Pakistan Journal of Botany 43:1629-1633.

Berzsenyi, Z., and D.Q. Lap. 2001. Effect of sowing time and $\mathrm{N}$ fertilization on the yield and yield stability of maize (Zea mays L.) hybrids between 1991- 2000. ActaAgron. Hung., 309-331.

Buriro, M., T.A. Bhutto, A.W. Gandahi, I.A. Kumbhar and Shar M.U. 2015. Effect of sowing dates on growth, yield and grain quality of hybrid maize. Journal of Basic \& Applied Sciences, 2015, 11, 553-558.

Carr, T., H. Yang and Ray C. 2016. Temporal variations of water productivity in irrigated corn: an analysis of factors influencing yield and water use across central nebraska. PLoS ONE 11(8):1-17.

Dehghani, H., A. Ebadi and A. Yousefi. 2006. Biplot analysis of genotype by environment interaction for barley yield in Iran. Agron. J., 98: 388-393.

El-Garhi I.; K. Matter; N. Ainar and Sidrak N. 2007. Irrigation scheduling of corn (Zea mays L.) in middle Egypt. Zagazig J. Agric. Res., 34(3): 501-512.

EL-Marsafawy, Samia M.; A.Y Salib; M.A. Aly and Eid H.M. 1998. Row width and nitrogen levels impacts on water relations, growth and yield of maize crop.Third Conference of Meteorology and Sustainable development, Cairo, Egypt.

El-Refaie, M. and Khater A.N. 1996. Effect of irrigation systems and quantities of water applied on yield and water relations of maize. Egypt. J. Appl. Sci., 11(4): 329-343.

EL-Sharkawy, Amal F.; M.Y. Bondok and Abdel Maksoud H.H. 2008. Irrigating maize crop via different ETO- estimating formulae and consequent influence on crop water use and water use efficiency. Minufiya J. Agric. Res., 33 (4): 941 954.
El-Tantawy, Manal M., S. Ouda and Khalil F.A. 2007. Irrigation Scheduling for Maize Grown under Middle Egypt Conditions. Research Journal of Agriculture and Biological Sciences, 3(5): 456 - 462.

FAO, 2017.The future of food and agriculture - Trends and challenges. Rome.

Feyzbakhsh, M. T.;B. Kamkar, H. Mokhtarpour and AsadiM. E. 2015. Effect of soil water management and different sowing dates on maize yield and water use efficiency under drip irrigation system. Archives of Agronomy and Soil Science. Volume 61, Issue 11:1581-1592.

Hansen, V.W.; D.W. Israelsen and Stringharm D.E. 1979. Irrigation Principle and Practices, fourth ed. Johns Willey \&Sons, New York, USA.

Hussain, M., W. Bashir, S. Farooq and Rehim A. 2013. Root Development, Allometry and Productivity of Maize Hybrids under Terminal Drought Sown by Varying Method. Int. J. Agric. Biol., Vol. 15, No. 6:1243-1250.

Igbadun, H.E., B.A. Salim, A.K.P.R. Tarimo and H.F. Mahoo. 2008. Effects of deficit irrigation scheduling on yields and soil water balance of irrigated maize. Irrig. Sci. 27: 11-23.

Irmak, S., K. Djaman and D. R. Rudnick (2016). Effect of full and limited irrigation amount and frequency on subsurface drip $\square$ irrigated maize evapotranspiration, yield, water use efficiency, and yield response factors. Irrig. Sci., 34:271-286.

Karrou, M.; T. Oweis; R. Abou El Enein and Sherif M. 2012. Yield and water productivity of maize and wheat under deficit and raised bed irrigation practices in Egypt. African Journal of Agricultural Research, Vol. 7(11):1755-1760.

Khan, Abdul Ghaffar, Anwar-ul-Hassan, Muhammad Iqbal and EhsanUllah. 2015. Assessing the performance of different irrigation techniques to enhance the water use efficiency and yield of maize under deficit water supply. Soil Environ. 34(2): 166-179.

Khan, M. B., F. Yousaf, Hussain, M. W. Haq, Dong-J. Lee and M. Farooq. 2012b. Influence of planting methods on root development, crop productivity and water use efficiency in maize hybrids. Chilean J. Agric. Res., 72(4): 556 - 563.

Khan, M.B., R. Rafiq, M. Hussain, M. Farooq, and K. Jabran. 2012a. Ridge sowing improves root system, phosphorous uptake, growth and yield of maize (Zea mays L.) hybrids. Journal of Animal and Plant Sciences 22:309-317.

Koca, Y. O. and O.Canavar. 2014. The Effect of Sowing Date on Yield and yield Components and Seed Quality of Corn (Zea mays L.). Scientific Papers. Series A. Agronomy, Vol. LVII, 227 - 231.

Kranz, W.L, S. Irmak, S.J. van Donk, C.D. Yonts, and D.L Martin. 2008. Irrigation management for corn. University of Nebraska NebGuide G1850.

Kuscu, H. and A. O. Demir (2012). Responses of maize to full and limited irrigation at different plant growth stages. U. Ü. ZIRAAT FAKÜLTESİ DERGİSI, Cilt 26, Sayı 2, 15-27 (Journal of Agricultural Faculty of Uludag University). 
Lamm, F.R., Manges, H.L., Stone, L.R., Khan, A.H., Rogers, D.H., 1995. Water requirement of subsurface drip-irrigated corn in northwest Kansas. Trans. ASAE. 38(2): 441-448.

Leibman, M., J. J. Shryock, M. J. Clements, M. A. Hall, P. J. Loida, Amanda L. McClerren, Zoe P. M., J. R. Phillips, Elena A. Rice and S. B. Stark (2014). Comparative analysis of maize (Zea mays) crop performance: natural variation, incremental improvements and economic impacts. Plant Biotechnology Journal. 12(7): 941-950.

Lundy, M. 2015. Managing Irrigated Corn under Drought Conditions: General principles of water productivity under conditions of water-deficits. DRAFT DROUGHT TIP, AUGUST 2015, University of California, Agriculture and Natural Resources

Mahgoub, G. M. A.; M. M. A. Osman; H. H. AbdelMaksoud and HodaKh. A. El-Mekser 2013. Effect of ridge spacing and irrigation patterns on growth, grain yield, yield components and water productivity for maize crop. J. Plant Production, Mansoura Univ., vol. 4 (11): 1725 - 1738.

Molden, D. 2003. A water-productivity framework for understanding and action. In: Kijne, J.W., Barker, R., Molden, D. (Eds.), Water Productivity in Agriculture: Limits and Opportunities for Improvement. International Water Management Institute, Colombo, Sri Lanka, pp. 1-18.

Molua, E. L. and C. M. Lambi .2006. Assessing the impact of climate on crop water use and crop productivity: The CROPWAT analysis of three districts in Cameroon. In project report "Climate Change Impacts on and Adaptation of Agro-ecological Systems in Africa".
Sabaghnia, D.N.H., and S.H. Sabaghpour 2008. Graphic analysis of genotype $\times$ environment interaction of lentil yield in Iran. Agron J., 100: 760-764.

Saqib, M., M.S.I. Zamir, A. Tanveer, A.U.H. Ahmad. 2012. Agro-Economic evaluation of various maize hybrids under different planting patterns. CercetăriAgronomiceîn Moldova Vol. XLV, No. 3 (151):63- 70.

Sárvári, M., and Z. Futó. 2000. Correlation between the sowing date, yield and grain moisture content of maize hybrids on chernozem soil. DebreceniEgyetemAgrártudományiKözlemények J., 1: 32-41.

Steel, R.G.D., and J.H. Torrie. 1984. Principles and Procedures of Statistics. $2^{\text {nd }}$ ed McGraw Hill Book Co. Inc. Singapore, pp.172-177.

Swelam, A. and Y. Atta. 2012. Impact of planting dates on irrigation requirements and water productivity of maize in Egypt Delta. Agricultural Engineering Research Journal, 2 (1): 01-12.

Yan, W., M.S. Kang, B. Ma, S. Woods and P.L. Cornelius. 2007. GGE Biplot vs. AMMI analysis of genotype-by-environment data. Crop Sci., 47: 643-655.

Zamir, M.S.I; G. Yasin; H.M.R. Javeed; A.U.H. Ahmad; A. Tanveer and M. Yas. 2013. Effect of different sowing techniques and mulches on the growth and yield behavior of spring planted maize. CercetăriAgronomice in Moldova, Vol. XLVI, No. 1 (153): 77- 82.

Zwart, S. J. and W. G.M. Bastiaanssen. 2004. Review of measured crop water productivity values for irrigated wheat, rice, cotton and maize. Agricultural Water Management, 69: 115-133.

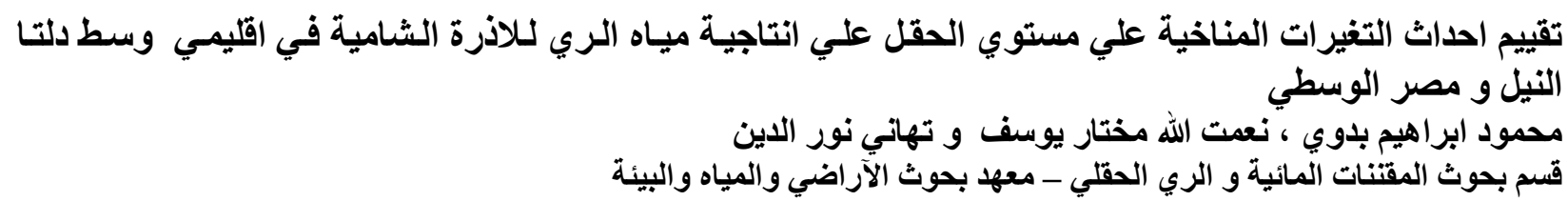

اقيمت تجربة حقلية في الموسم الصيفي 2015 في كلا من محطة البحوث الزر اعيـة بـالجمبزة (وسط دلتا النيل) ومحطة البحوث

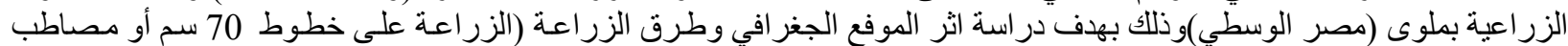

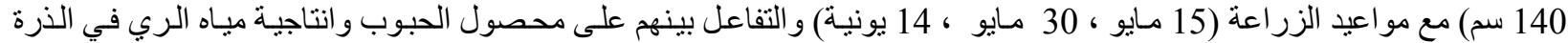

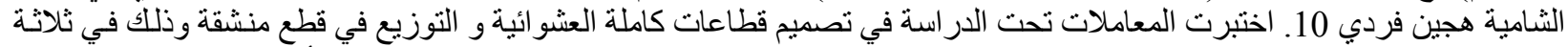

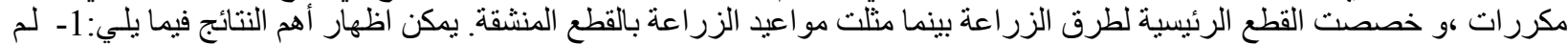

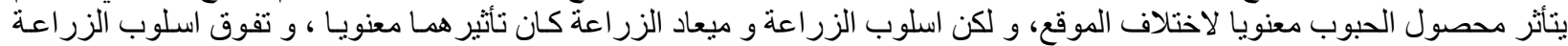

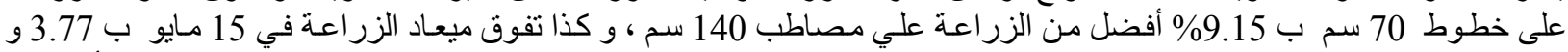

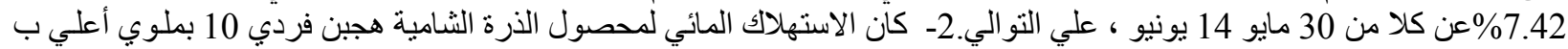

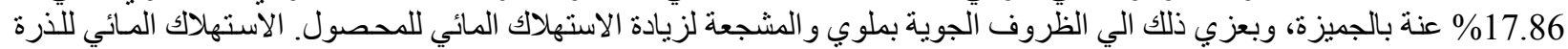

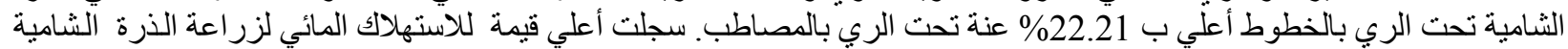

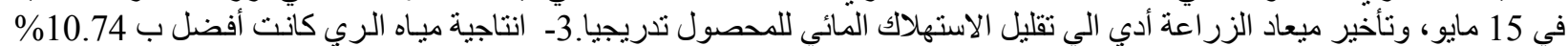

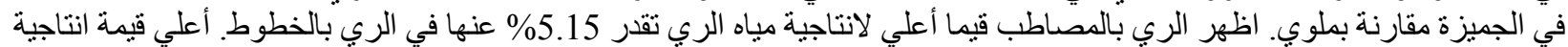

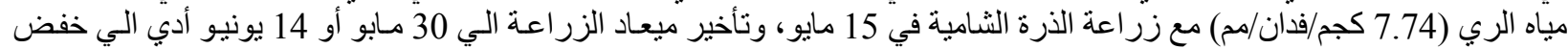

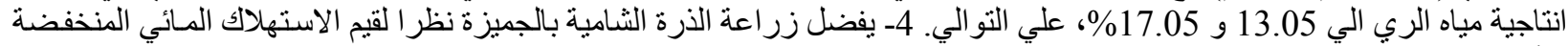
و أيضا لتفوق انتاجية مياه الري. 